\title{
ANALISIS CADANGAN MANFAAT DENGAN MENGGUNAKAN METODE RETROSPEKTIF PADA ASURANSI JIWA BERJANGKA
}

\author{
Bachyurah, Ikhsan Maulidi, Intan Syahrini, Nurmaulidar \\ Jurusan Matematika, Universitas Syiah Kuala \\ *Corresponding Author Email: ikhsanmaulidi@unsyiah.ac.id
}

\begin{abstract}
The insurance company is a company that protects its customers from an unwanted event in the future. Life insurance company must prepare a benefit reserve fund to be given to customers if the customers experience a risk of death in the future. Therefore, insurance company must manage the benefit reserve fund so that the company does not have loss. The method used to calculate the value of benefit reserve was a retrospective method. The purposes of this study are to calculate both the amount of annual net premiums and the amount of benefit reserves in term life insurance. The results of the calculation of annual net premiums for large annual premiums for expenditures that are greater than those greater for the same period. While the value of insurance reserves will continue to increase at the beginning of the insurance contract begins and the value of insurance reserves will continue to increase towards zero at the end of the insurance contract. This is because at the beginning of the company insurance payments obtained from annual net premium payments will be greater than the amount of benefits that must be approved.
\end{abstract}

Keywords: premiums, term life insurance, benefit reserves, retrospective methods.

\begin{abstract}
ABSTRAK
Perusahaan asuransi merupakan salah satu perusahaan yang melindungi nasabahnya dari suatu kejadian yang tidak diinginkan di masa yang akan datang. Perusahaan asuransi jiwa harus menyiapkan dana cadangan manfaat untuk diberikan kepada nasabah, jika nasabah mengalami risiko kematian di masa yang akan datang. Oleh sebab itu, perusahaan asuransi harus mengelola dana cadangan manfaat agar perusahaan tidak mengalami kerugian. Tujuan dari penelitian ini adalah menghitung besar premi bersih tahunan dan menghitung besar cadangan manfaat pada asuransi jiwa berjangka. Metode yang digunakan untuk menghitung nilai cadangan manfaat adalah metode retrospektif. Hasil perhitungan premi bersih tahunan menyatakan bahwa besar premi bersih tahunan untuk nasabah yang berusia lanjut lebih besar daripada nasabah yang berusia lebih muda untuk jangka waktu yang sama. Sedangkan nilai cadangan manfaat asuransi akan terus meningkat pada awal kontrak asuransi dimulai dan nilai cadangan asuransi akan terus menurun menuju nol pada akhir kontrak asuransi. Hal ini dikarenakan pada awal kontrak asuransi pendapatan perusahaan yang diperoleh dari pembayaran premi bersih tahunan akan lebih besar daripada jumlah manfaat yang harus dibayarkan.
\end{abstract}

Kata kunci: premi, asuransi jiwa berjangka, cadangan manfaat, metode retrospektif.

\section{PENDAHULUAN}

Asuransi merupakan usaha kerja sama antara perusahaan asuransi dan nasabah, dimana perusahaan akan memberikan sejumlah dana kepada nasabah pada waktu tertentu sesuai 
dengan perjanjian sebagai pengganti premi yang dibayar nasabah (Mandur, 2011). Perusahaan asuransi merupakan salah satu perusahaan yang melindungi nasabahnya dari suatu kejadian yang tidak diinginkan di masa yang akan datang. Perusahaan asuransi memiliki beberapa jenis asuransi, salah satunya asuransi jiwa (Achdijat, 1990).

Asuransi jiwa merupakan asuransi untuk mengurangi risiko nasabah asuransi di masa yang akan datang, seperti risiko kematian. Menurut jangka waktu pertanggungan, asuransi jiwa memiliki tiga jenis asuransi jiwa, yaitu asuransi jiwa seumur hidup, asuransi jiwa berjangka dan asuransi jiwa dwiguna (Fabozzi, 1999). Pada umumnya, semua jenis asuransi jiwa akan menyiapkan dana manfaat oleh perusahaan asuransi. Tetapi pada asuransi jiwa berjangka manfaat akan diberikan kepada ahli waris nasabah, apabila nasabah mengalami kejadian yang tidak diinginkan selama masa asuransi masih berlaku.

Perusahaan asuransi jiwa akan menyiapkan manfaat asuransi untuk setiap nasabah dengan melakukan pengelolaan dana premi seperti menentukan jumlah premi yang dibayar oleh nasabah asuransi. Penentuan jumlah premi ini dipengaruhi oleh beberapa faktor, seperti faktor mortalitas yang berfungsi untuk memperkirakan jumlah tingkat kematian dari sekelompok orang yang hidup dalam jangka waktu tertentu, tingkat suku bunga yang telah disesuaikan oleh perusahaan asuransi serta manfaat asuransi yang akan diterima ahli waris nasabah asuransi tersebut (Syahrini, 2019). Perusahaan asuransi yang akan memberikan manfaat asuransi kepada setiap ahli waris nasabah harus memiliki dana cadangan manfaat asuransi.

Cadangan manfaat asuransi jiwa merupakan kewajiban perusahaan asuransi untuk menyiapkan sejumlah dana manfaat untuk setiap nasabah asuransi. Menurut Futami (1993) cadangan manfaat dapat dihitung dengan dua metode, yaitu metode prospektif dan metode retrospektif. Metode retrospektif merupakan perhitungan cadangannya berdasarkan jumlah total pendapatan perusahaan asuransi di masa lalu sampai dilakukan perhitungan cadangan manfaat, dikurangi dengan jumlah pengeluaran perusahaan asuransi di masa lalu untuk setiap nasabah asuransi.

Ewys (2017), meneliti tentang Perhitungan Nilai Cadangan Retrospektif Premi Tahunan Asuransi Joint Life Dwiguna. Hasil yang diperoleh pada penelitiannya menyatakan bahwa nilai cadangan manfaat terus meningkat setiap tahunnya hingga pada akhir tahun ke-21 dan nilai cadangan manfaat mengalami penurunan hingga pada tahun ke-31. Tahun ke-31 nilai cadangan manfaat pada akhir tahun asuransi untuk nasabah asuransi seumur hidup adalah 
negatif, tetapi dalam asuransi nilai cadangan tersebut dapat ditafsirkan sama dengan nol.

Berdasarkan latar belakang di atas, penelitian ini akan menghitung besar nilai premi bersih tahunan untuk asuransi jiwa berjangka dan nilai cadangan manfaat asuransi jiwa berjangka dengan menggunakan metode retrospektif. Beberapa penelitian terkait penentuan cadangan manfaat juga dapat dilihat pada Thaibah et.al (2015).

\section{METODOLOGI}

\subsection{Tempat Dan Waktu Penelitian}

Penelitian ini dimulai pada bulan Desember 2018 sampai dengan bulan Juli 2019 di UPT Perpustakaan Universitas Syiah Kuala dan Laboratorium Komputasi Dasar, Jurusan Matematika, Fakultas Matematika dan Ilmu Pengetahuan Alam, Universitas Syiah Kuala.

\subsection{Alat Dan Bahan}

Alat yang digunakan dalam penelitian ini adalah aplikasi Microsoft Excel 2010 yang berfungsi untuk menghitung nilai cadangan manfaat dengan menggunakan metode retrospektif dari asuransi jiwa berjangka.

\subsection{Asumsi Kasus}

Pada penelitian ini data yang digunakan adalah tabel mortalitas Indonesia tahun 2011 serta perhitungan cadangan manfaat untuk nasabah yang berusia 25 tahun dan 30 tahun.

\subsection{Prosedur Penelitian}

Prosedur penelitian ini dilakukan seperti berikut ini:

a. Studi literatur

Studi literatur menjadi langkah awal untuk melakukan penelitian. Studi literatur bertujuan untuk mempelajari dan memahami teori-teori yang digunakan untuk penelitian. Beberapa buku referensi dasar yang digunakan dapat dilihat di Larson (1951), Darmawi, (2000), Djojosoedarso (2003), Sembiring, R.K. (1986), dan Sembiring, R.K. (1988).

b. Tabel mortalitas

Tabel mortalitas yang digunakan tabel mortalitas Indonesia tahun 2011 (Hendriyanto, 2018). Tabel mortalitas ini terdiri dari 5 kolom, yaitu $x$ meyatakan usia, $l_{x}$ menyatakan jumlah orang yang hidup pada usia $x$ tahun, $d_{x}$ menyatakan jumlah orang yang meninggal pada usia $x$ tahun, ${ }_{t} p_{x}$ menyatakan peluang seseorang dapat bertahan hidup pada usia $x$ tahun hingga $x+t$ tahun dan ${ }_{t} q_{x}$ menyatakan peluang seseorang yang berusia $x$ tahun akan meninggal sebelum mencapai usia $x+t$ tahun. 
c. Menghitung nilai komutasi

Nilai-nilai komutasi ini dihitung berdasarkan tabel mortalitas Indonesia tahun 2011 dengan tingkat suku bunga sebesar 2,5\%. Suku bunga yang digunakan adalah suku bunga majemuk (Frensidy, 2006). Simbol komutasi yang digunakan adalah $D_{x=v^{x}} l_{x}$ menyatakan hasil perkalian antara jumlah orang yang hidup pada usia $x$ tahun dengan fungsi diskonto pangkat $x, N_{x}$ menyatakan penjumlahan dari $D_{x+i}$ dengan $i \geq 0, \quad C_{x}=d_{x} v^{x+1}$ menyatakan hasil perkalian jumlah orang yang meninggal pada usia $x$ tahun dengan fungsi diskonto pangkat $x+1$, dan $M_{x}$ menyatakan penjumlahan dari $C_{x+i}$ dengan $i \geq 0$.

d. Menentukan nilai anuitas awal asuransi jiwa berjangka

Anuitas awal dari asuransi jiwa berjangka merupakan serangkaian pembayaran yang dilakukan pada awal periode selama jangka waktu tertentu. Nilai anuitas awal dapat dihitung dengan persamaan berikut:

$$
\ddot{a}_{x: \bar{n} \mid}=\frac{N_{x}-N_{x+n}}{D_{x}} .
$$

e. Menentukan nilai tunai premi tunggal bersih asuransi jiwa berjangka

Premi tunggal bersih ini dihitung selama $n$ tahun untuk asuransi jiwa berjangka dengan persamaan berikut:

$$
A_{x: n \mid}^{1}=\frac{M_{x}-M_{x+n}}{D_{x}} .
$$

f. Menentukan nilai premi bersih tahunan asuransi jiwa berjangka

Besar nilai premi bersih tahunan untuk usia nasabah $x$ tahun dengan jangka waktu asuransi $n$ tahun dapat dihitung dengan persamaan berikut:

$$
P_{x: \bar{n} \mid}^{1}=\frac{A_{x: \bar{n} \mid}^{1}}{\ddot{a}_{x: \bar{n} \mid}} .
$$

g. Menentukan nilai endowment murni

Nilai endowment murni dihitung selama $n$ tahun untuk asuransi jiwa berjangka dengan persamaan berikut:

$$
{ }_{t} E_{x}=\frac{D_{x+t}}{D_{x}} .
$$

h. Menghitung nilai cadangan manfaat asuransi jiwa berjangka

Perhitungan besar nilai cadangan manfaat pada asuransi jiwa berjangka 
menggunakan metode retrospektif dengan persamaan berikut:

$$
{ }_{t} V_{x: \bar{n} \mid}^{1}=\frac{1}{{ }_{t} E_{x}}\left(P_{x: \bar{n} \mid}^{1} \ddot{a}_{x: \bar{t} \mid}-A_{x: \bar{t} \mid}^{1}\right)
$$

(Bowers et al. 1997).

\section{HASIL DAN PEMBAHASAN}

\subsection{Menghitung Nilai Komutasi}

Perusahaan asuransi menggunakan beberapa simbol komutasi untuk mempermudah perhitungan yang dilakukannya dalam menentukan besar nilai anuitas hidup berjangka dan besar nilai premi. Perhitungan nilai-niai komutasi ini berdasarkan tabel mortalitas Indonesia tahun 2011. Beberapa simbol komutasi yang digunakan oleh perusahaan asuransi jiwa adalah $D_{x}, N_{x}, C_{x}$ dan $M_{x}$ yang disusun dalam bentuk tabel komutasi.

\subsection{Menghitung Nilai Anuitas Hidup Awal Berjangka}

Dalam penelitian ini akan dihitung nilai anuitas hidup awal berjangka untuk nasabah asuransi berjangka yang berusia 25 tahun dan 30 tahun.

\subsubsection{Besar nilai anuitas hidup awal berjangka untuk nasabah yang berusia 25 tahun}

Perusahaan asuransi akan menghitung nilai tunai dari anuitas hidup awal selama 10 tahun dan 20 tahun untuk nasabah yang berusia 25 tahun. Nilai anuitas hidup awal berjangka selama 10 tahun dapat dihitung dengan menggunakan persamaan (2.1) berikut

$$
\begin{aligned}
\ddot{a}_{25: \overline{10 \mid}} & =\frac{N_{25}-N_{35}}{D_{25}} \\
& =\frac{1518358,39-1044926,451}{52955,7499} \\
& =8,940142285 .
\end{aligned}
$$

Jadi, nilai tunai dari anuitas hidup awal dengan jangka waktu 10 tahun untuk nasabah yang berusia 25 tahun adalah 8,94014228 satuan. Dengan menggunakan cara yang sama, dapat dihitung nilai anuitas hidup awal dengan jangka waktu 20 tahun adalah sebesar 15,85574588 satuan. Besar nilai tunai dari anuitas hidup awal berjangka untuk nasabah asuransi yang berusia 25 tahun pada tahun ke-t, dimana $t=1,2,3, \ldots, 20$.

\subsubsection{Besar nilai anuitas hidup awal berjangka untuk nasabah yang berusia 30 tahun}

Perusahaan asuransi akan menghitung nilai tunai dari anuitas hidup awal selama 10 
tahun dan 20 tahun untuk nasabah yang berusia 30 tahun. Besar nilai anuitas hidup awal berjangka selama 10 tahun dengan menggunakan persamaan (2.1), sehingga didapatkan

$$
\begin{aligned}
\ddot{a}_{30: \overline{10 \mid}} & =\frac{N_{30}-N_{40}}{D_{30}} \\
& =\frac{1266588,004-849888,1521}{46620,19044} \\
& =8,93818425 .
\end{aligned}
$$

Jadi, nilai tunai dari anuitas hidup awal dengan jangka waktu 10 tahun untuk nasabah yang berusia 30 tahun adalah 8,93818425 satuan. Dengan cara yang sama didapatkan nilai anuitas hidup awal dengan jangka waktu 20 tahun dengan untuk nasabah yang berusia 30 tahun adalah sebesar 15,8143302 satuan. Besar nilai tunai dari anuitas hidup awal berjangka untuk nasabah asuransi yang berusia 30 tahun pada tahun ke- $t$, dimana $t=1,2,3, \ldots, 20$.

\subsection{Menghitung Besar Nilai Premi Tunggal Bersih}

Premi tunggal bersih merupakan premi yang dibayarkan sekaligus pada waktu kontrak polis ditandatangani oleh nasabah asuransi. Perusahaan asuransi dapat menghitung nilai premi tunggal bersih berjangka untuk nasabah yang berusia 25 tahun dan 30 tahun dengan manfaat sebesar 1 satuan. Perhitungan nilai premi tunggal bersih ini berdasarkan nilai-nilai komutasi yang telah diperoleh.

\subsubsection{Besar nilai premi tunggal bersih untuk nasabah yang berusia 25 tahun}

Nasabah asuransi yang berusia 25 tahun akan membuat kontrak polis asuransi jiwa berjangka selama 10 tahun dan 20 tahun. Besar nilai premi tunggal bersih untuk jangka waktu 10 tahun adalah sebesar (dengan menggunakan persamaan 2.2):

$$
\begin{aligned}
A_{25: \overline{10 \mid}}^{1} & =\frac{M_{25}-M_{35}}{D_{25}} \\
& =\frac{15922,61843-15551,31715}{52955,7499} \\
& =0,007011539 .
\end{aligned}
$$

Jadi, besar nilai premi tunggal bersih yang harus dibayarkan untuk nasabah yang berusia 25 tahun dengan jangka waktu asuransi selama 10 tahun adalah sebesar 0,007011539 satuan. Dengan menggunakan cara yang sama dapat dihitung nilai premi tunggal bersih selama 20 tahun adalah sebesar 0,017176091 satuan. Besar nilai premi tunggal bersih untuk nasabah yang berusia 25 tahun pada tahun ke-t, dimana $t=1,2, \ldots, 20$ juga dapat ditentukan. 


\subsubsection{Besar nilai premi tunggal bersih untuk nasabah yang berusia 30 tahun}

Nasabah asuransi yang berusia 30 tahun akan membuat kontrak polis asuransi jiwa berjangka selama 10 tahun dan 20 tahun. Besar nilai premi tunggal bersih untuk jangka waktu 10 tahun dengan menggunakan persamaan (2.2) adalah sebesar:

$$
\begin{aligned}
A_{30: \overline{10 \mid}}^{1} & =\frac{M_{30}-M_{40}}{D_{30}} \\
& =\frac{15727,8001-15341,29902}{46620,19044} \\
& =0,008290423 .
\end{aligned}
$$

Jadi, besar nilai premi tunggal bersih yang harus dibayarkan untuk nasabah yang berusia 30 tahun dengan jangka waktu asuransi selama 10 tahun adalah sebesar 0,008290423 satuan. Besar nilai premi tunggal bersih untuk nasabah yang berusia 30 tahun dan manfaat asurasi sebesar 1 satuan pada tahun ke-t, dimana $t=1,2, \ldots, 20$ lebih lanjut juga dapat ditentukan.

\subsection{Menghitung Nilai Premi Bersih Tahunan}

\subsubsection{Nilai premi bersih tahunan untuk nasabah yang berusia 25 tahun}

Besar premi bersih tahunan untuk nasabah yang berusia 25 tahun dengan jangka waktu asuransi 10 tahun dengan persamaan (2.3) adalah sebesar:

$$
P_{25: \overline{10 \mid}}^{1}=\frac{A_{25: \overline{10 \mid}}^{1}}{\ddot{a}_{25: \overline{10 \mid}}}=\frac{0,007011539}{8.940142285}=0,00078428 .
$$

Jadi, besar nilai premi bersih tahunan untuk nasabah asuransi jiwa berjangka 10 tahun yang berusia 25 tahun adalah 0,00078428 satuan. Dengan menggunakan cara yang sama, jumlah premi bersih tahunan untuk jangka waktu 20 tahun adalah sebesar 0,00108327 satuan.

\subsubsection{Nilai premi bersih tahunan untuk nasabah yang berusia 30 tahun}

Besar premi bersih tahunan untuk nasabah yang berusia 30 tahun dengan jangka waktu asuransi 10 tahun adalah sebesar:

$$
P_{30: \overline{10 \mid}}^{1}=\frac{A_{30: \overline{10 \mid}}^{1}}{\ddot{a}_{30: \overline{10 \mid}}}=\frac{0,00829042}{8,9381843}=0,0009275 .
$$

Jadi, besar nilai premi bersih tahunan untuk nasabah asuransi jiwa berjangka 10 tahun yang berusia 30 tahun adalah 0,0009275 satuan. Dengan menggunakan cara yang sama, jumlah premi bersih tahunan untuk jangka waktu 20 tahun adalah sebesar 0,001693384 satuan. Jumlah pembayaran premi bersih tahunan yang harus dibayarkan oleh setiap nasabah 
asuransi dapat dilihat pada Tabel 1.

Tabel 1 Besar premi bersih tahunan

\begin{tabular}{cccc}
\hline \multirow{2}{*}{$\begin{array}{c}\text { Usia } x \\
\text { tahun }\end{array}$} & $\begin{array}{c}\text { Jangka } \\
\text { waktu } \\
\text { asuransi }\end{array}$ & $\begin{array}{c}\text { Manfaat sebesar 1 satuan } \\
\text { (satuan) }\end{array}$ & $\begin{array}{c}\text { Manfaat sebesar } \\
R p 100.000 .000,00 \\
(R p)\end{array}$ \\
\hline \multirow{2}{*}{25} & 10 & 0,000784276 & 78.428 \\
& 20 & 0,001083272 & 108.327 \\
30 & 10 & 0,000927529 & 92.753 \\
& 20 & 0,001693384 & 169.338 \\
\hline
\end{tabular}

Tabel 1 menjelaskan bahwa besaran premi bersih tahunan yang harus dibayarkan oleh setiap nasabah asuransi jiwa berjangka untuk usia nasabah 25 tahun dan 30 tahun dengan jangka waktu yang telah ditentukan. Besaran premi bersih tahunan ini akan lebih murah untuk nasabah yang berusia lebih muda dengan jangka waktu yang sama.

\subsection{Menghitung Nilai Endowment Murni}

Endowment murni merupakan suatu pembayaran manfaat yang dilakukan pada akhir tahun asuransi jika nasabah mampu bertahan hidup. Perhitungan besar nilai endowment murni berdasarkan nilai komutasi dihitung dengan menggunakan persamaan (2.4).

\subsubsection{Besar nilai endowment murni untuk nasabah yang berusia 25 tahun}

Besar nilai endowment murni untuk nasabah yang berusia 25 tahun dengan jangka waktu 10 tahun dengan persamaan (2.4) adalah sebesar:

$$
{ }_{10} E_{25}=\frac{D_{35}}{D_{25}}=\frac{41037,32816}{52955,7499}=0,774936211
$$

Jadi, nilai tunai endoment murni untuk nasabah yang berusia 25 tahun dengan jangka waktu asuransi 10 tahun adalah sebesar 0,774936211 satuan. Dengan menggunakan cara yang sama, besar nilai endowment murni dengan jangka waktu asuransi 20 tahun adalah sebesar 0,5960984 .

\subsubsection{Besar nilai endowment murni untuk nasabah yang berusia 30 tahun}

Besar nilai endowment murni untuk nasabah yang berusia 30 tahun dengan jangka waktu 10 tahun adalah sebesar:

$$
{ }_{10} E_{30}=\frac{D_{40}}{D_{30}}=\frac{36070,27834}{46620,19044}=0,773705083 .
$$

Jadi, nilai tunai endoment murni untuk nasabah yang berusia 30 tahun dengan jangka waktu asuransi 10 tahun adalah sebesar 0,773705083 satuan. Dengan menggunakan cara yang 
sama, besar nilai endowment murni dengan jangka waktu asuransi 20 tahun adalah sebesar 0,587504902 .

\subsection{Menghitung Besar Nilai Cadangan Manfaat}

Cadangan manfaat asuransi merupakan dana yang harus disiapkan oleh perusahaan asuransi. Perhitungan cadangan manfaat ini berdasarkan nilai pendapatan dan pengeluaran dari perusahaan asuransi. Perhitungan nilai cadangan manfaat dengan metode retrospektif ini menggunakan persamaan (2.5).

\subsubsection{Jangka waktu pertanggungan asuransi 10 tahun}

Diasumsikan cadangan manfaat pada tahun pertama asuransi untuk nasabah yang berusia 25 tahun adalah sebesar:

$$
\begin{aligned}
{ }_{1} V_{25: \overline{10 \mid}}^{1} & =\frac{1}{{ }_{1} E_{25}}\left(P_{25: \overline{10 \mid}}^{1} \ddot{a}_{25: \overline{1} \mid}-A_{25: \overline{1} \mid}^{1}\right) \\
{ }_{1} V_{25: \overline{10 \mid}}^{1} & =\frac{1}{0,974784964}[(0,00078428 \times 1)-0,000824792] \\
& =-4,15641 \times 10^{-5} .
\end{aligned}
$$

Jadi, besar cadangan manfaat pada tahun pertama asuransi untuk nasabah yang berusia 25 tahun dengan jangka waktu 10 tahun adalah sebesar $-4,15641 \times 10^{-5}$ satuan. Karena cadangan manfaat yang dihasilkan bernilai negatif maka tidak ada nilai cadangan yang harus disiapkan oleh perusahaan asuransi. Hal ini dapat terjadi jika jumlah cadangan manfaat yang dimiliki oleh perusahaan melebihi dari jumlah manfaat yang harus dikeluarkan oleh perusahaan asuransi.

Sedangkan besar nilai cadangan manfaat pada tahun pertama untuk nasabah yang berusia 30 tahun adalah sebesar 0,0001941 satuan. Dengan menggunakan cara yang sama, didapatkan nilai cadangan manfaat pada tahun ke- $t$, dimana $t=1,2,3, \ldots, 1$.

\subsubsection{Jangka waktu pertanggungan asuransi 20 tahun}

Diasumsikan cadangan manfaat pada tahun pertama asuransi untuk nasabah yang berusia 30 tahun adalah sebesar:

$$
\begin{aligned}
{ }_{1} V_{25: \overline{20 \mid}}^{1} & =\frac{1}{{ }_{1} E_{25}}\left(P_{25: \overline{20 \mid} \cdot{ }^{1}} \ddot{a}_{25: \overline{1} \mid}-A_{25: \overline{1} \mid}^{1}\right) \\
{ }_{1} V_{25: \overline{10 \mid}}^{1}= & \frac{1}{0,974784964}[(0,00108327 \times 1)-0,000824792] \\
= & 0,00026517
\end{aligned}
$$

Jadi, besar cadangan manfaat pada tahun pertama asuransi untuk nasabah yang berusia 
25 tahun dengan jangka waktu 20 tahun adalah sebesar 0,00026517 satuan. Sedangkan besar nilai cadangan manfaat pada tahun pertama untuk nasabah yang berusia 30 tahun adalah sebesar 0,000979728 satuan. Dengan menggunakan cara yang sama, didapatkan nilai cadangan manfaat pada tahun ke- $t$, dimana $t=1,2,3, \ldots, 20$.

\subsection{Perbandingan Besar Nilai Cadangan Manfaat Asuransi Jiwa Berjangka}

Dari perhitungan cadangan manfaat yang telah dilakukan maka dapat dilihat perbandingan besar nilai cadangan manfaat asuransi yang disediakan oleh perusahaan asuransi untuk setiap nasabah asuransi. Perbandingan nilai cadangan tersebut dapat dilihat pada Tabel 2.

Tabel 2 Besar nilai cadangan manfaat asuransi jiwa berjangka dengan cadangan manfaat sebesar $R p 100.000 .000,00$

\begin{tabular}{ccccc}
\hline \multicolumn{5}{c}{ Cadangan manfaat asuransi dengan manfaat $R p 100.000 .000,00$} \\
& \multicolumn{4}{c}{$(R p)$} \\
\cline { 2 - 5 } & Jangka waktu 10 tahun & Jangka waktu 20 tahun \\
\cline { 2 - 5 } 1 & Usia 25 tahun & Usia 30 tahun & Usia 25 tahun & Usia 30 tahun \\
\hline 2 & -4.156 & 19.413 & 26.517 & 97.973 \\
3 & -7.472 & 35.174 & 54.667 & 194.325 \\
4 & -5.836 & 48.205 & 88.577 & 290.035 \\
5 & -133 & 60.478 & 127.383 & 387.129 \\
6 & 5.661 & 70.946 & 167.133 & 484.620 \\
7 & 10.526 & 76.476 & 206.830 & 579.452 \\
8 & 11.362 & 74.871 & 243.406 & 669.507 \\
9 & 9.082 & 62.835 & 277.797 & 751.589 \\
10 & 5.647 & 39.029 & 311.985 & 824.448 \\
11 & 0 & 0 & 344.941 & 884.750 \\
12 & & & 373.556 & 929.048 \\
13 & & & 395.658 & 952.749 \\
14 & & & 407.981 & 956.226 \\
15 & & & 409.214 & 936.750 \\
16 & & & 395.938 & 889.402 \\
17 & & & 364.617 & 809.038 \\
18 & & & 310.549 & 687.128 \\
19 & & & 234.020 & 516.789 \\
20 & & & 132.191 & 289.658 \\
\hline & & & 0 & 0 \\
\hline
\end{tabular}

Tabel 2 menjelaskan bahwa nasabah asuransi yang berusia 25 tahun dan 30 tahun 


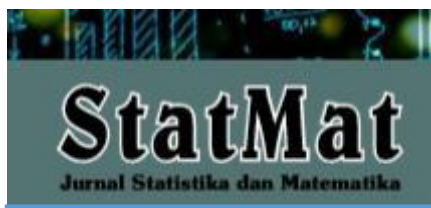

P-ISSN: 2655-3724

STATMAT (Jurnal Statistik dan Matematika), Vol. 2, No. 1, 2020

Halaman: 1-13

@Prodi S-1 Matematika FMIPA Unpam

membeli polis asuransi jiwa berjangka 10 tahun dengan manfaat $R p 100.000 .000,00$. Nilai cadangan manfaat yang harus disiapkan oleh perusahaan asuransi untuk nasabah yang berusia 25 tahun bernilai negatif pada tahun pertama sampai tahun ke empat. Cadangan manfaat yang bernilai negatif ini dianggap nol oleh perusahaan dimana perusahaan tidak perlu menyiapkan dana cadangan manfaat pada 4 tahun pertama.

Tabel 2 juga menjelaskan nasabah yang berusia 30 tahun membeli polis asuransi jiwa berjangka selama 20 tahun dengan cadangan manfaat sebesar $R p 100.000 .000,00$. Pada tahun pertama sampai tahun ke-14 asuransi nilai cadangan manfaat yang harus disiapkan oleh perusahaan asuransi terus meningkat sedangkan pada tahun selanjutnya sampai masa polis asuransi berakhir nilai cadangan manfaat asuransi menurun hingga menuju nol. Hal ini dikarenakan pada awal polis asuransi, perusahan telah mendapatkan pendapatan perusahaan lebih besar dibandingkan besar manfaat yang haus dikeluarkan oleh perusahaan asuransi. Sehingga pada akhir polis asuransi, perusahaan tidak perlu menyiapkan cadangan manfaat yang terlalu besar seperti pada awal polis asuransi.

Tabel 2 dapat disajikan secara grafik adalah sebagai berikut:

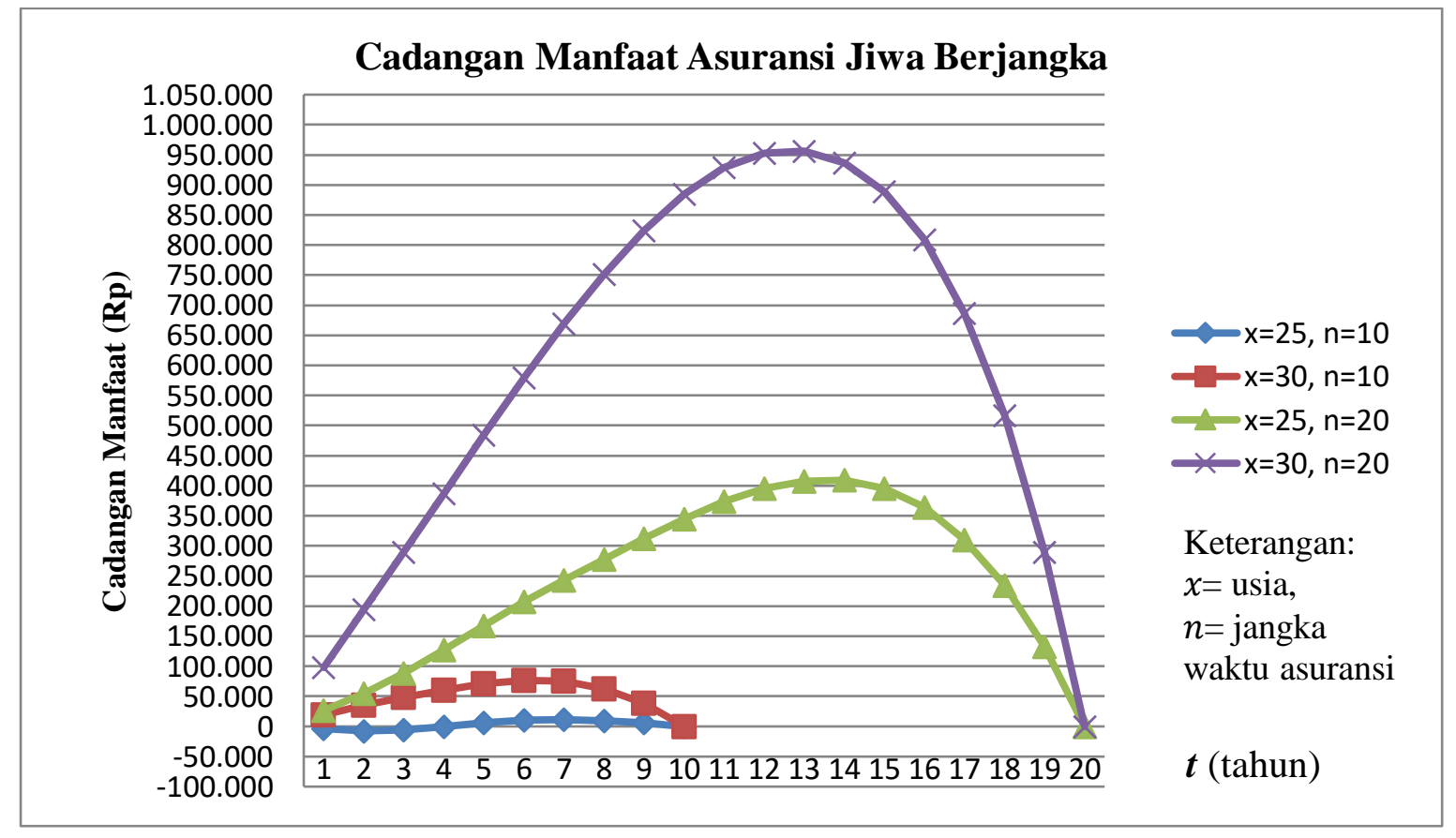

Gambar 1. Grafik cadangan manfaat asuransi jiwa berjangka

Gambar 1 merupakan grafik garis dari besar nilai cadangan manfaat asuransi jiwa berjangka yang harus disiapkan oleh perusahaan asuransi untuk setiap nasabah asuransi. Garis 
berwarna biru menunjukkan cadangan manfaat untuk nasabah yang berusia 25 tahun dan garis berwarna merah menunjukkan cadangan manfaat untuk nasabah yang berusia 30 tahun dengan jangka waktu 10 tahun. Sedangkan garis berwarna hijau menunjukkan cadangan manfaat untuk nasabah yang berusia 25 tahun dan garis berwarna ungu menunjukkan cadangan manfaat untuk nasabah yang berusia 30 tahun dengan jangka waktu 20 tahun. Cadangan manfaat asuransi jiwa untuk jangka waktu 10 tahun akan terus meningkat hingga tahun ke-7 sedangkan untuk jangka waktu 20 tahun akan terus meningkat hingga tahun ke-14 asuransi. Sedangkan pada tahun selanjutnya sampai akhir tahun asuransi nilai cadangan manfaat menurun menuju nol. Hal ini disebabkan karena pada awal asuransi dimulai pendapatan perusahaan asuransi lebih besar daripada pengeluaran perusahaan, sehingga pada akhir asuransi perusahaan tidak perlu menyiapkan dana cadangan manfaat yang berjumlah besar seperti pada awal asuransi. Pada 4 tahun pertama perusahaan tidak perlu menyiapkan dana cadangan manfaat untuk nasabah asuransi yang berusia 25 tahun dengan jangka waktu 10 tahun, dikarenakan tingkat kematian yang rendah.

\section{SIMPULAN}

Berdasarkan hasil dan pembahasan yang telah dilakukan dengan menggunakan metode retrospektif dapat disimpulkan bahwa:

1. Perusahaan asuransi akan menyiapkan dana cadangan manfaat untuk nasabah yang berusia 25 tahun dengan jangka waktu 10 tahun pada tahun ke-5 sampai tahun ke-9 asuransi. Tahun pertama sampai tahun keempat asuransi perusahaan asuransi tidak perlu menyiapkan dana cadangan manfaat, hal ini dikarenakan tingkat kematian sangat rendah.

2. Nilai cadangan manfaat asuransi untuk nasabah yang berusia 25 tahun dan 30 tahun dengan jangka waktu 10 tahun akan terus meningkat hingga tahun ke-7 asuransi dan jangka waktu 20 tahun akan terus meningkat hingga tahun ke-14 asuransi. Sedangkan pada tahun selanjutnya sampai akhir tahun asuransi nilai cadangan manfaat menurun menuju nol. Karena pada awal polis asuransi pendapatan perusahaan akan lebih besar daripada pengeluaran perusahaan asuransi. Sehingga pada akhir polis asuransi perusahaan telah mengalami pendapatan yang cukup pada akhir masa jangka waktu asuransi dan tidak perlu menyiapkan cadangan manfaat pada akhir jangka waktu asuransi. 


\section{DAFTAR PUSTAKA}

Achdijat, D. (1990). Prinsip-Prinsip Aktuaria pada Asuransi Jiwa. Gunadarma, Jakarta.

Bowers, N.L., Gerber H.U., \& Hickman, J.C. (1997). Actuarial Mathematics. The Society of Actuaries, United States of America.

Darmawi, H. (2000). Manajemen Asuransi. PT Bumi Aksara, Jakarta.

Djojosoedarso, S. (2003). Prinsip-Prinsip Manajemen Risiko dan Asuransi. Salemba Empat, Jakarta.

Ewys, C.E. (2017). Perhitungan nilai Cadangan Retrospektif Premi Tahunan Asuransi Joint Life Dwiguna (Tugas Akhir) Universitas Lampung, Bandar Lampung.

Fabozzi, F.J. (1999). Manajemen Investasi. Salemba Empat, Jakarta.

Frensidy, B. (2006). Matematika Keuangan. Salemba Empat, Jakarta.

Futami, T. (1993). Matematika Asuransi Jiwa Bagian I. Oriental Life Insurance Cultural Development Centre, Inc. Tokyo, Japan.

Hendriyanto, F. (2018). Penerapan Model Vasicek pada Premi Bersih Asuransi Jiwa Dwiguna (Endoment) (Tugas Akhir) UIN Sunan Kalijaga, Yogyakarta.

Larson, R. (1951). Life Insurance Matemathic. John Wiley and Sons Inc, New York.

Mandur, K. (2011). Penentuan Premi Bersih dan Premi Kotor Pada Asuransi Jiwa (Tugas Akhir) Universitas Sanata Dharma, Yogyakarta.

Sembiring, R.K. (1986). Asuransi I Modul 1-9. Karunika Jakarta, Jakarta.

Sembiring, R.K. (1988). Asuransi II Modul 1-9. Karunika Jakarta, Jakarta.

Syahrini I., Nurmaulidar N., Maulidi I., Alfira M. (2019). Aplikasi Metode Entry Age Normal dan Projected UnitCredit untuk Iuran Normal dan Kewajiban Aktuaria pada Dana Pensiun PNS. Journal of Data Analysis. 2(1), p. 43-52, 2623-2286.

Thaibah SR, Ruhiyat, Erliana W. 2015. Penentuan Premi dan Cadangan Manfaat pada Beberapa Asuransi Jiwa dengan Memperhitungkan Biaya (Tugas Akhir) Institut Pertanian Bogor, Bogor. 